\title{
Exploring Students' Learning Strategy: Will Listening to English Song Enhance Speaking Skill?
}

\author{
Sutini Lailatuzzakiya \\ English Language Education Department \\ UIN Sunan Ampel \\ Surabaya, Indonesia \\ lailatuzzakiyah@gmail.com
}

\author{
Nila Sari \\ English Language Education Department \\ UIN Sunan Ampel \\ Surabaya, Indonesia \\ nilafebil@gmail.com
}

\author{
Jihan Nailal hana \\ English Language Education Department \\ UIN Sunan Ampel \\ Surabaya, Indonesia \\ jihannaila16@gmail.com
}

\begin{abstract}
Speaking is a process of communication toexpress our thought or ideas through oral production. It also becomes one of the main elements in some aspects of life such as economic, education, social, and political. This research is aimed at investigating the significant correlation between listening habits to English song with the students' speakingskills. This research used a correlational study, a kind of quantitative research that determines whether the two variables are correlated or not. The data were taken from questionnaire and document of score of speaking English. The population of this research is the students of English Education Department at StateIslamic University of Sunan Ampel Surabaya. Then, the sample of this study is English Education Department students in $3^{\text {rd }}$ semester.There are 30 students of English Education Department in $3^{\text {rd }}$ semester that were chosen as the sample size. The results of this research show that there is no correlation between listening habits to English song with the students speaking skills. The $r$ coefficient (Pearson Correlation) of this research is $-\mathbf{0 . 0 7 9}$ and the sig. (2-tailed) is 0.677 . It can be described that $0.67>0.05$. It meansthat there is no correlation between listening habits to English song with the students' speaking skills. So, it can be concluded that there are other factors that affect students' speaking skills.
\end{abstract}

Keywords: speaking skills, learning strategy, listening to English songs

\section{INTRODUCTION}

As a kind of productive skill, speaking will be the main elements for people to communicate with others in some aspects of life, such as political, economic, education, and social. Aye \& Phyu (2015) argue that speaking skill is needed in the whole life aspects, especially in this industrial revolution 4.0. In terms of education, Speaking is one of the important skills that must be learned by all students. Speaking ability is good for a career goal because when someone has good skills in speaking, they can communicate well to each other and make the interactions smoothly. Furthermore, Tahir (2015) believes that someone who succeeded in learning a foreign language is someone who can speak well. Students can be considered as having a good speaking skill is when they talk a lot and participate actively in the classroom. Sepahvand (2014) identifies interests and career goals. Thus, this skill should be continuously taught for the students so that they can communicate the target language well.

Unfortunately, many students in Indonesia often get difficulties to speak English in the classroom or daily life. They keep speaking haltingly and often utilizing codemixing (English-Indonesia). It may be caused by several factors such as lack of practices of speaking English and lack of motivation to improve their English language skills. Gençoğlu (2011) points out that successful speaking English depends on the students' motivation, the chance to practice language, classroom atmosphere, and the methods used in the classroom. Moreover, the psychological factor can be the cause of the difficulty to speak English. A study from 
Haidara (2016) indicates that there are psychological factors which affect negatively on English speaking of Indonesian learners. They are fear of making a mistake, feeling shy, feeling hesitated and lack of confidence. It happens when they speak up in front of the class, and they are shy if they fail to produce an accurate one. Students feel inconfidence when they are talking to someone who can speak English fluently.

Another psychological factor is anxiety. English learners are anxious in speaking because they have no ability and less of practice in the class. Kayaoğlu \& Sağlamel (2013) on their study find several causes of language anxiety including linguistic difficulty, lack of grammatical understanding, cognitive challenges, lack of understanding in the original word, and teachers' role. The result shows that the most affected are the point of number one. Looking back to the factors of the difficulties of speaking English, the students should be in the situation when they are forced to speak in English.

To overcome this problem, therefore, it is indispensable for all the students to understand various strategies that are suitable for their needs. Cabaysa \& Baetiong (2010) reveal that Filipino students commonly use a combination of metacognitive, social/affective, and compensation strategies in speaking class. Moreover, developing an interactive way to practice a speaking skill is recommended for the students so that they have an interest in English. Listening English song, for example, is assumed can make the students integrate into English skills. The activity is simple and doable that most people love to do. Rubio \& Conesa (2015) note that the concept of the listening song has a positive effect on the classroom climates as it will give the feeling of enjoyment and a good time. When the students enjoy listening to English song, they indirectly will make an effort to learn to translate the lyrics of their English song.

In the previous studies which deal with listening English song, Gushendra (2017) highlights that there is a significant effect of using songs toward students' ability on vocabulary mastery at SMPN 1 Kampar Timur, Riau. Moreover, another research conducted by Listiyaningsih (2017) shows that the use of English songs technique gives a great contribution to vocabularies knowledge, pronunciation skill, and listening comprehension. Besides, in Iran, Moradi \& Shahrokhi (2014) proved that song or music has a better effect on children' pronunciation, intonation, and stress pattern recognition. However, there is still a need for investigating the effect of listening English song in other skill such as speaking skill in the level of college students of an Islamic university in Indonesia. It will prove whether the students who often listen to English song will have a higher score in speaking or not. This research was categorized into the habit, the frequency, the purposes, and the motivation of listening English song. Hence, this paper explores the significant correlation between listening habits to English song with the students' speaking skills. As the subject of the study, the researchers choose the students of the English Language Department at State Islamic University of Sunan Ampel Surabaya. In the end, this study will be beneficial for the teacher and students in the teaching and learning process. It will give any varieties of a teaching strategy that are suitable for them in order to overcome the students' difficulties in enhancing their English speaking skills.

\section{LITERATURE REVIEW}

\section{A. EFL Speaking Skills}

As human being, communication is needed to express our thought, idea to do everything, and as students we have to speak or communicate with our teacher in order to express our idea as long as in learning process (Richards, 2002). Hinkel (2005) defines speaking as a productive skill that is one of the principal language skills. Speaking should be taken aa process of oral production of language. Students need to be confident and have to understand about the knowledge of English, especially in terms of speaking skills. One of the advantages of spoken language is that speaking allows us to indicate a certain number of pauses, corrections, hesitations, and backtracking (Brown, 2001). Sproule (2006) explains that there are four general purposes of speaking including to persuade, to entertain, to inform, and to inspire.

Besides, Khamkhien (2010) points out some factors that influence students' speaking skill including age, native language, phonetic, ability, attitude, motivation, and experience in learning English. This statement is supported by Hamad (2013) stating that there are some factors that affect students' speaking skills which includes the use of mother tongue, afraid of using English in public, less contain exercise of speaking and discussion activities, less time and support from the teacher, speaking section less than listening. Furthermore, Brown (2004) highlights six scoring categories of oral proficiency including able to use the language accurately on all levels normally to professional needs, can understand and participate in any conversation with a high degree of precision of vocabulary, can understand any conversation within the range of his/her experience, able to use the language fluently on levels normally to professional needs, equivalent to educated native speaker, and can handle informal interpreting from and into language.

\section{B. Factors Affecting Speaking Difficulties}

In carrying out speaking, most of students get difficulties to speak, and one of the big problems is that they are afraid of making mistakes. Speaking is a difficult process in many ways to dissociate from listening. As Rizvi (2006) indicates that speaking is an interactive communicative process that includes listeners and speakers. In communicative process, speakers need to be confident to express their ideas and try to adapt their talk to the listeners. 
opportunities to the students for improving their higherorder thinking skills and enabling personalized learning (McQuiggan, 2015). to each other, they feel inferior when they are talking with someone who can speak better than them. Juhana (2012) states that affective or psychological factors can influence students' difficulties in speaking such as anxiety fear of mistakes, feeling shy, lack of motivation and lack of confidence. So anxiety is one of the psychological factors in speaking.

Findings by Kayaoglu \& Saglamel (2013) found that there are several causes of language anxiety including linguistic difficulty in form of lack of vocabulary, lack of grammatical understanding, and bad pronunciation; cognitive challenges in the form of feelings of fear cannot communicate, fear of feeling the test, fear of making mistakes, shame to fail in front of others, and low selfesteem; lack of understanding in the original word; and teacher's role who acts as catalyst and rein in the classroom.

According to Al Hosni (2014), he identifies that there are four factors that can cause the difficulties in speaking English including inhibition which means a situation when students fear of making mistakes, and fearful of criticism or simply shy; nothing to say which means a situation when students have lack motivation to express themselves; low or uneven participation which means a situation when students have lack opportunities to participate because of large classes and the tendency of some learners to dominate; and mother-tongue use which means learners use too much of mother tongue because they feel easier when they speak with their mother tongue.

\section{Students' Self-Regulated Learning in Speaking Skills}

Zimmerman (2002) defines self-regulated learning (SRL) as the selective use of some strategies that the learners mental process will be transformed into academic skills such as in the indivisual learning task. Therefore, it is supported by Aregu (2013) statements that self-regulated learning is when the studentas apply different strategies in order to try their best level to maximize their performance and manage their behaviour that will influence their learning process. In herbook, Nilson (2013) mentioned tha benefits of selfregulated learning. It enhances students' performance or achevement in learning, the deepness of students' awareness of learning, and the reflective and responsible professionalism. Therefore, the students can choose their own way in learning and the most comfortable strategy to be used.

There have been many SLR students opted to maximize their EFL performance, especially in speaking skills.

\section{A. Maximizing Android App}

Mobile devices have been proved to allow the students in providing new learning experiences, thereby they can participate in a community of practices outside the classroom (Kim, D. et al., 2013). Furthermore, it also gives

\section{$>$ Orai Application}

Related with a mobile device, one of the most popular android applications that support the EFL students' speaking skills is Orai. This application helps the students become confident and speak carefully in everyday life (Chang, 2017). Halimah, Lustyantie, \& Ibrahim (2018) believed that it is similar to speaking into the mirror. It offers interesting features that can solve some problems. They mentioned key features in Orai Application including 1) a recording practice which covers the number of filler words (Umm, you know, basically), the speed of speech, and the energy level (vocal clarity, performance tracking, audio recording, and playback), 2) reminder for practice (improvement process from day 1 to day 30), 3) instant speak insight and voice improve their speaking skills without waiting for the learning process in the classroom.

\section{$>\quad$ Social Media}

In the socio-affective strategy, Darwanto (2014) mentioned the students' strategy named cooperation. In this strategy, the students have high motivation for practising their speaking with others, but they only have a little chance to speak, so they prefer to practice their speaking ability through the social media such as using Facebook or video call using other applications.

\section{B. Students' Habit in Watching English Movie}

It is a non-formal strategy that students can do everywhere and every time in order to improve their speaking ability (Navyani, 2016). By having the habit of watching an English movie, students will be able to learn a new language, to improve knowledge, enrich the information, etc. The movie is a learning media for ESL / EFL students. Therefore, they will be exposed to their target language and get a comprehensible input (Ikram, 2017).

\section{Joining/Participating in Communities/Activities related to Education/Hibbies when Studying Abroad}

When studying abroad, students can participate in some activities that will help them to improve English proficiency. Liu (2011) outlined that there are five out-ofclass English learning strategies, including volunteering, working at a part-time job, choosing a homestay, making a presentation, and participating in leisure activities. Volunteering here means teaching English as a second language in China, so she will teach, explain, and communicate with her students using English. Then, through working at a part-time job, it may give them opportunities to learn new vocabulary by interacting with a variety of people that has different in speaking styles and accents. Choosing a homestay also helps students to learn analytics. Therefore, the students may use this application to 
authentic English by interacting with native English speaker about the local culture and social events. Moreover, joining an organization (making presentation) encourage the student to speak in public and to learn pronunciation and grammar. Finally, students are also needed to participate in leisure activities such as watching television, listening to English song, watching English movies, attending live theatre, and writing e-mails in English.

\section{The Importance of Listening English Song in Improving Students' Speaking Skills}

A melody on the music may provide sequential information that has good potential for making the accurate reconstruction of the information that has been gotten (Salcedo, 2012). Music may also be an important part of cognitive development (Copple and Bredekamp, 2009). Besides, music develops memory through melody, which is connected to the emotions (Hirsh, 2004). Vocabulary and idiomatic expressions can be obtained by learners through music and points of grammar that have been studied can be reviewed (Arleo, 2000).

There are several parts of music; one of them is a song which can be sung for people through words (Grifee, 2001). The song consists of words which express ideas, feelings, and experiences of the writer. Songs also put an enjoyable and effective way to introduce culture and encourage students (Murphey, 2010). English songs can be the good media which people or students can use to improve English proficiency which is as the foreign/second language.

In the educational field, active learning can be supported by the use of music in teaching. It can make the brain be more active and receptive for learning. If both the right and left hemispheres of the brain are connected with music, it will be influenced by the maximizing of learning. Therefore, activities like listening to music can activate both rights and left brain easier in processing the information (Salsedo, 2010). In line with Salsedo (2010), Alamsyah (2015) mentions that music influences the brain amazingly, the brain relaxes and will be ready to learn something. It is the conditions of the brain after listening to music or song. Through listening to music, in learning pronunciation will be more focused and avoid the mistakes because of the continuing practice through listening English song.

Listening to songs shows appreciations of the lyrics, rhythms, vocal, and melody and also an attempt to understand the meaning of the song. Good listeners are just as active listeners when listening to the speakers when the speakers speak. This is because, within the process of listening, they are successful in analysing the song through critical thinking (Brown, 2001). Moreover, listening to English songs will be beneficial for people, especially for the teaching and learning process. Through listening to songs, students can improve their English proficiency, not only in the listening skill but also speaking skill, vocabulary mastery, pronunciation, etc. Various English methods can be used to facilitate learners to learn English easily. Farida and Nurtela (2015) note there are some benefits of using English song in learning which can motivate students to be more enthusiastic, can easily understand the information, and will catch learners' interest.

However, listening English songs does not only give the benefit in teaching English context but also in another context including culture and diversity (Arleo, 2000) that means songs do not only give access to cultural information but also bring diversity into the classroom it can be highlighted from the taste of the various group. Few researchers have addressed the issue of listening English song as the strategy in learning English. Some of the researchers' investigation of listening English song is elaborated below.

Gushendra (2017) worked on 54 Junior High School students of SMPN 1 Kampar Timur Riau to find out how English Song improves the students' vocabulary mastery. The researcher used experimental research as a research design. The students were divided into two groups named experimental class and control class. The result is there is a significant effect of using songs toward students' ability on vocabulary mastery. Another research conducted by Listiyaningsih (2017) showed that the use of English songs technique gives a great contribution to vocabularies knowledge, pronunciation skill, and listening comprehension. She used a qualitative approach by interviewing five informants who are students majoring of English Education of the fifth semester and using various literature sources; book, internal, journal, and other.

In Iran, Moradi \& Shahrokhi (2014) placed the students, the ages of 9-12, into two groups. The first group is as the control group, and the second group is as the experimental group that used the Song Time book. It proved that song or music has a better effect on children' pronunciation, intonation, and stress pattern recognition. Besides, Kahyany (2011) used 35 students in Pendidikan University to find out whether using English songs can improve English pronunciation. The researcher chose the famous songs such as Old Mac Donald had a farm and The Mulberry Bush to perform his project, and he found that music has a great effect on students' pronunciation.

All those previous studies are linked together by choosing English song as the learning strategy in improving some skills in English. Therefore, in this present study, the researchers are going to investigate the correlation between listening habits to English song with the students' speaking skills. This paper, therefore, sheds new light on the learning strategy of using English song in enhancing the students' English speaking score.

\section{METHOD}

This chapter discusses the process of conducting the study. It is included as research design, participants (population and sample), instrument, data collection, and data analysis. 


\section{Research Design}

The purpose of this study is to investigate the significant correlation between the frequencies of listening English song with the students' speaking skills.

In this study, the non-experimental research design was used. The researcher used a correlational study, a kind of quantitative research that determines whether the two variables are correlated or not. There are three possible results of this kind of research; a positive correlation, a negative correlation, and no correlation at all.

\section{Population \& Sample}

In this study, the population is the students of English Education Department at the State Islamic University of Sunan Ampel Surabaya. Then, the sample of the study is English Education Department students in 3rd semester. There are 30 students of English Education Department in 3 rd semester that were chosen as the sample size.

There are 4 Spoken English classes in English Department, yet this research only used a class in which the lecturer voluntarily participated in this research by giving the final score of speaking English class as the data and allowed the students as the participants of this research.

\section{Instrument}

\section{Questionnaire}

A questionnaire is a set of systematically structured questions which are used to get information from the respondent. It is supported by Brown (2001) theory. He points out that questionnaire is any written instruments that present respondents with a series of questions or statements to which they are to react either by writing out the respondents' answers or selecting from among existing answers. The questionnaire was modified from three sources, including Chen and Chen (2009), Millington (2011), and Shen (2009).The questionnaire consists of 18 items, and it consists of three categories; the frequency, types of song, and theme of the song.

2. Document of the score of students speaking Another instrument for collecting the data is a document of the score of students in spoken class in the 3rdsemesterof English Education Department of Islamic University of Sunan Ampel Surabaya. The instrument is needed to know students' speaking proficiency. This research needs the document of students' final score in spoken class then collect the final score of students speaking in the spoken class.

\section{Procedure}

Data collection was administered from the research questions. Since the research was intended to investigate the correlation between frequency of listening English songs and speaking ability. This research used two techniques.
They were questionnaire and document of a score of speaking English. Questionnaire of the frequency of listening English songs was collected first. This questionnaire is used to identify students' frequency of research. There was some aspect of the score of speaking English performance, but this research used final score of speaking English.

\section{Data Analysis}

This research used some techniques in analysing the data, which are analysed respectively from the research questions. In analysing the students listening habits to English song, descriptive statistics were employed. Then, the researcher also analysed students' speaking score through descriptive statistics using SPPS program. According to Supranto (2007), this research uses the table of categories of the listening habit of English songs to measure students' habit of listening to English songs as the following:

\begin{tabular}{|c|c|c|}
\hline No & Interval & Categories \\
\hline 1 & $3.1-4$ & Always \\
\hline 2 & $2.1-3$ & Often \\
\hline 3 & $1-2$ & Seldom \\
\hline
\end{tabular}

Table 3.1. Categorization of the listening habit of English songs.

Through this analysis, the researcher found the minimum score, maximum score, and the mean. Besides, the researcher also measured students' speaking score by classified them at the level where they stood. The researcher used a table of the students rank or level in speaking, as suggested by Pandiya (2013):

\begin{tabular}{|c|c|}
\hline $\begin{array}{c}\text { The score of } \\
\text { ability level }\end{array}$ & Category \\
\hline $10-39$ & Very poor \\
\hline $40-59$ & Poor \\
\hline $60-74$ & Average \\
\hline $75-84$ & Good \\
\hline $85-100$ & Very good \\
\hline
\end{tabular}

Table 3.2. Level of speaking ability

In answering the last research question about the correlation between the frequency of listening English skills and the students' speaking score, the research computes and analyses the correlation between two variables: the frequency of listening English skills and the students' speaking score. The researcher used bivariate correlate technique. Through this technique, the researcher got the $r$ coefficient (Pearson Correlation) that can describe the correlation between the $\mathrm{X}$ variable and $\mathrm{Y}$ variable, as below: 
2) Students' habit of listening to an English song

The result of students' habit of listening to English songs would be shown as the following: weak or can say there is no correlation between the variables.

\begin{tabular}{|l|l|}
\hline $0.20-0.40$ & $\begin{array}{l}\text { The correlation between the } \mathrm{X} \\
\text { variable and Y variable is weak. }\end{array}$ \\
\hline $0.40-0.70$ & $\begin{array}{l}\text { The correlation between the } \mathrm{X} \\
\text { variable and Y variable is enough. }\end{array}$ \\
\hline $0.70-0.90$ & $\begin{array}{l}\text { The correlation between the X } \\
\text { variable and Y variable is strong. }\end{array}$ \\
\hline $0.90-1.00$ & $\begin{array}{l}\text { The correlation between the X } \\
\text { variable and Y variable is very } \\
\text { strong. }\end{array}$ \\
\hline
\end{tabular}

Table 3.3. the correlation coefficient (r)

\section{FINDINGS AND DISCUSSION}

In reference to the data analysis, the following presents the research findings and discussion about students' speaking score, students' ha bit on listening English song, and the correlation between two students' speaking score and students' habit on listening English song. Each is presented below:

1) Students' speaking skills

Descriptive Statistic

\begin{tabular}{|l|c|c|c|c|c|}
\hline & N & Min & Max & Mean & $\begin{array}{c}\text { Std. } \\
\text { Deviati } \\
\text { on }\end{array}$ \\
\hline $\begin{array}{l}\text { Score } \\
\text { of } \\
\text { speakin } \\
\text { g }\end{array}$ & 30 & 72 & 95 & 85.70 & 4.977 \\
\hline $\begin{array}{l}\text { Valid } \\
\text { N } \\
\text { (listwis } \\
\text { e) }\end{array}$ & 30 & & & & \\
\hline
\end{tabular}

Table 4.1. the result of students' speaking ablitiy

Based on the data above, Based on the data above, it can be seen that the minimum score of students' speaking ability is 72 , and the maximum score is 95 . Therefore, the mean of English speaking score from 30 participants in this research is 85.70 with standard deviation 4.97 which means that the students have a very good level of speaking ability as written on table 3.2 in data analysis.
Item Statistics

\begin{tabular}{|c|c|c|c|}
\hline \multicolumn{4}{|c|}{ Item Statistics } \\
\hline & Mean & Std. Deviation & $\mathrm{N}$ \\
\hline $\mathrm{P} 1$ & 3.30 & .750 & 30 \\
\hline $\mathrm{P} 2$ & 3.17 & .950 & 30 \\
\hline P3 & 2.87 & .860 & 30 \\
\hline $\mathrm{P} 4$ & 3.10 & .712 & 30 \\
\hline P5 & 3.07 & .740 & 30 \\
\hline P6 & 2.90 & 1.094 & 30 \\
\hline P7 & 2.50 & .861 & 30 \\
\hline P8 & 2.47 & .776 & 30 \\
\hline P9 & 2.57 & .728 & 30 \\
\hline $\mathrm{P} 10$ & 3.30 & .750 & 30 \\
\hline P11 & 3.13 & .776 & 30 \\
\hline P12 & 3.23 & .728 & 30 \\
\hline P13 & 2.30 & 1.088 & 30 \\
\hline P14 & 3.07 & 1.048 & 30 \\
\hline P15 & 2.47 & .860 & 30 \\
\hline P16 & 2.73 & .785 & 30 \\
\hline P17 & 2.63 & .890 & 30 \\
\hline P18 & 2.30 & .952 & 30 \\
\hline P19 & 2.13 & .730 & 30 \\
\hline
\end{tabular}

Table 4.2. The result of students' habit of listening to English songs

Based on the result above, it showed the highest mean score was P! (3.30). It means the student was categorized always listening to songs every day. On the other hand, the lowest mean score was P19 (2.13). It means the student was categorized often listen to English songs before they go to campus in order to be more motivated to learn English. Thus categories, are according to Supranto (2007) that provided in the data analysis in table 3.2. Moreover, P2, P4, P5, P10, $\mathrm{P} 11, \mathrm{P} 12$, and $\mathrm{P} 14$ were categorized in always, and the rest questions which are P3, P5, P6, P7, P8, P9, P13, P15, P16, $\mathrm{P} 17$, and $\mathrm{P} 18$ were categorized in often.

3) The correlation between students' speaking skillsand students' habit of listening to an English song 


\begin{tabular}{|l|l|c|c|}
\hline & & $\begin{array}{c}\text { Listening } \\
\text { Habit }\end{array}$ & Spoken Score \\
\hline $\begin{array}{l}\text { Listening } \\
\text { Habit }\end{array}$ & $\begin{array}{l}\text { Pearson } \\
\text { correlation }\end{array}$ & 1 & -.79 \\
\hline & Sig (2-tailed) & N & .677 \\
\hline Spoken Score & $\begin{array}{l}\text { Pearson } \\
\text { correlation }\end{array}$ & -.79 & 30 \\
\hline & Sig (2-tailed) & .677 & 1 \\
\hline & $\mathrm{N}$ & 30 & 30 \\
\hline
\end{tabular}

Table 4.3. the correlation between students' habit of listening to English songs and speaking ability.

From the calculation above, the researcher describes that $r$ coefficient (Pearson Correlation) is -0.079 and the sig. (2-tailed) 0.677. Moreover, $\mathrm{r}$ result included in the first category of interpretation which is $0.00-0.02$ that describes there is a very weak correlation between the $\mathrm{X}$ variable and $\mathrm{Y}$ variable. It also can be seen from sig. (2-tailed). For the result, it described that $0.67>0.05$. It means that there is no correlation between spoken English skill and students' habit of listening to an English song.

\section{CONCLUSION}

Based on the findings of this research, it shows that there is no correlation between students' habit of listening to English song and spoken English skill. It can be concluded from the $r$ coefficient (Pearson Correlation) that points out the result of this research is -0.079 and the sih. (2-tailed) is 0.677 , it can be described that $0.67>0.05$. Moreover, the significant correlation can be seen from the significant value. If the significant value $<0.05$ so, there is a significant correlation, but if the significant value $>0.05$, it means that there is no significant correlation. Furthermore, from the result above, it is considered that there are other factors that affect the students' speaking skill. There are some experts that supportthese findings. According to Huang (2006), students like to ise well-known words or simple expressions to communicate with each other, rather than giving up when they have difficulties conveying the meaning of words. Besides, the students often use gestures to help them get the meaning and use eye contact to attract the attention of their listeners. It is another thing that affects students' speaking ability. According to Hamad (2013), are English language teaching methods, English language exercises, and the teaching and learning environment.

Limitation and Recommendation
This study This study is carried out in an attempt to examine the correlation between the frequency of listening to an English song and students' speaking English skills. In collecting the data, the researchers only used the teacher's final score data from spoken class in the second semester of students' English Education Department of UIN Sunan Ampel Surabaya. So, for the next researchers who want to develop this topic, it will be better if they use the speaking test to measure students' speaking skill when collecting data in order to get the better understanding on how to assess their speaking in terms of pronunciation, fluency, grammar, vocabulary, comprehension, and task. It also gives a more significant result that two variables (frequency of listening to an English song and students' speaking skills) are correlated in a positive or negative.

\section{REFERENCES}

[1] Al Hosni, S. (2014). Speaking Difficulties Encountered by Young EFL Learners. International Journal on Studies in EnglishLanguage and Literature (IJSELL), 2(6), 22-30

[2] Amelia, Q.A. (2013). Not Just Wanna Have Fun: Teaching Listening Skills with Songs. Advances in Language and LiteracyStudies, 4, 96

[3] Andrew \& Melinda. (2018). Listen to the Music: Using Songs inListening and Speaking Classes. americanenglish.state.gov/english-teaching-forum.

[4] Aregu, B. B. (2013). Enhancing self-regulated learning in teaching spoken communication: Does it affect speaking efficacy and performance? Electronic Journal of Foreign LanguageTeaching, 10(1), 96-109.

[5] Ashtiani, F.T. (2015). The Effect of English Verbal Songs onConnected Speech Aspects of Adult English Learners' Speech Production. Australian International Academic Centre: Advancesin Language and Literary Studies. 6(1).

[6] Aye, K. K. \& Phyu, K. L. (2015). Developing students' speaking skill through short stories. Yangon University of Education Research Journal, 5(1), 1-11.

[7] Brown, H. D. (2001). Teaching by Principle An InteractiveApproach to Language Pedagogy. San Fransisco: Longman

[8] Brown, H. D. (2004). LANGUAGE ASSESSMENT Principles andClassroom Practices. San Fransisco: Longman.

[9] Cabaysa, C., \&Baetiong, L. (2010). Language Learning Strategies of Students at Different Levels of Speaking Proficiency. Education Quarterly.

[10] Chang, M. (2017). Interview with Danish Dhamani, CoFounderof Orai - AI Artisan. Retrieved from https://aiartisan.wordpress.com/2017/11/27/interview-withdanish-dhamani-co-founder-of-orai/

[11] Coskun, A. (2016). Causes of The 'I Can Understand English, But I Can't Speak' Syndrome In Turkey. i-manager's Journal onEnglish Language Teaching, 7 (3).

[12] Darwanto, A. (2014). Strategies for Developing Speaking Skill Used By Students of English Education Department: a CaseStudy. Publication Articles of the University of Surakarta.

[13] Gushendra, R. (2018). AN EXPERIMENTAL STUDY:IMPROVING STUDENTS' VOCABULARY MASTERY BYUSING ENGLISH SONGS. Indonesian Journal of IntegratedEnglish Language Teaching.https://doi.org/10.24014/ijielt.v3i1.3968

[14] Haidara, Y. (2016). Psychological Factor Affecting English Speaking Performance for the English Learners in Indonesia. Universal Journal of Educational Research 4(7): 1501-1505.

[15] Halimah, Halimah\&Lustyantie, Ninuk\&,Gufran\& Ibrahim,

Ali.(2018).STUDENTS'PERCEPTIONONTHEIMPLEMENT ATION OF ORAI APPLICATION IN CLL METHOD IN 
TEACHING SPEAKING. JEELS (Journal of English Education and Linguistics Studies).

[16] Hamad, M. M. (2013). Factors Negatively Affect Speaking Skills at Saudi Colleges for Girls in the South. Canadian Center ofScience and Education, 87-97.

[17] Hinkel, E. (2005). Handbook of Research in Second Language Teaching and Learning. Mahwah, N.J: Lawrence Erlbaum

[18] Ikram, D. N. (2017). TheRelationship between Students'Frequency of Teaching English Movie and Students' VocabularyKnowledge (A Correlational Study at Eighth Grade of MTs Izzatul Islam - Parung in Academic Year 2016/2017).SyarifHidayatullah State Islamic University Jakarta. Retrieved from http://repository.uinjkt.ac.id/dspace/bitstream/123456789/3645 3/ 1/Dzawin Nurlkram-FITK

[19] Jo McDonough, C. S. (2013). MATERIALS AND METHODS INELT A TEACHER'S GUIDE Third Edition. UK: WileyBlackwell.

[20] Juhana. (2012). Psychological Factors that Hinder Students from Speaking in English Class (A case study in a Senior High School in South Tangerang, Banten, Indonesia). Journal of Education and Practice, 3 (12). 100-110.

[21] Kayaoglu, M. N., \&Saglamel, H. (2013). Students' Perceptions ofLanguage Anxiety in Speaking Classes. Journal of History Culture and Art Research, 2 (2), 142-160

[22] Khamkhien, A. (2010). Thai Learners' English Pronunciation Competence: Lesson Learned from Word Stress Assignment. Journal of Language Teaching and Research, 757-764.

[23] Kim, D., Rueckert, D., Kim, D.-J., \&Seo, D. (2013). Students' perceptions and experiences of mobile learning. LanguageLearning \& Technology, 17(3), 52-73. Retrieved fromhttp://lit.msu.edu/issues/october2013/kimetal.pdf

[24] Listiyaningsih, T. (2017). The Influence of Listening English Song to Improve Listening Skill in Listening Class. E)Academica, 1(1), 2579-9703.

[25] Malasari, Susanti. (2017). Android Application to ImproveSenior High School Students' Speaking Skill. Yogyakarta: TheGraduate Program in English Language Studies, Sanata Dharma University.

[26] McQuiggan, S. (2015). Mobile Learning: A Handbook forDevelopers, Educators, and Learners; John Wiley \& Sons:Hoboken, NJ, USA.

[27] Moradi, F., \& Shahrokhi, M. (2014). The effect of listening to music on Iranian children's segmental and supra segmental pronunciation. English Language Teaching, 7(6), 128-142. https://doi.org/10.5539/elt.v7n6p128

[28] Navyani, B. (2016). The correlation between students' habit in watching English movies and their speaking ability at SMAN 9 Malang THESIS.

[29] Nilson, L. (2013). Creating self-regulated learners: Strategies tostrengthenstudents' self-awareness and learning skills. Sterling,Virginia: Stylus Publishing, LLC

[30] Richards \& Renandya. (2002). Methodology in LanguageTeaching An Anthology of Current Practice. New York:Cambridge University Press.

[31] Rizvi, M. A. (2005). Effective Technical Communication. New York, NY: Mc. Graw Hill

[32] Sari, D. K. (2006). The Difficulties in Speaking English on theBasis of the Perception of the Second Year Student of SMANegeri 18 Palembang. (Undergraduate Thesis).UniversitasBrawijaya, Palembang, Indonesia.

[33] Sepahvand, H. (2014). The effect of oral reproduction of short stories on speaking skill in Iranian high school students (case study: khorramabad, Iran). International Journal of Science and Research (IJSR), 3(7), 1847-1851.

[34] Shin, K.G. (2017). Get Up and Sing! Get Up and Move! Using Songs and Movement with Young Learners ofEnglish. americanenglish.state.gov/english-teaching-forum.

[35] Tahir, S. Z. A. (2015). Improving Students' Speaking Skill through Yahoo Messenger at the University of Iqra Buru. International Journal of Language and Linguistics, 3(3): 174181. DOI: $10.11648 /$ j.ijll.20150303.20.

[36] Zimmerman, Barry. (2002). Becoming a Self-Regulated Learner: An Overview. Theory Into Practice. 41. 64-70. 